\title{
Strategi Penyuluhan di Kawasan Konservasi (Kasus Taman Nasional Kepulauan Togean)
}

\author{
Extension Strategies in the Conservation Area \\ (Case Togean Islands National Park)
}

\author{
Muhd Nur Sangadji ${ }^{1}$, Sumardjo ${ }^{2}$, Pang S Asngari ${ }^{2}$ dan Soenarmo ${ }^{3}$ \\ ${ }^{1}$ Universitas Tadulako, ${ }^{2}$ Institut Pertanian Bogor, ${ }^{3}$ Kementerian Pertanian RI
}

\begin{abstract}
The aim of this research are (1) To describe the factors influences the community participation on management of Togean Island National Park. (2) To analyze the role of extension and it's correlation to the community participation. (3). To formulate an extension strategy to increase the community participation on management of Togean Island National Park. The research was conducted in Togean Island National Park in Central Sulawesi on August to Septembre 2008 and March to April 2009. Five variables are used to measure the community participation by using Structural Equation Model (SEM) and LISEREL 8.30 sofware. Those variables are internal characteristic, extension process, eksternal factor, community capacity and community participation. The result of research shown that extension proccess have a significant effect on the community capacity. Community capacity have a significant effect to the community participation on management of Togean Island National Park. The strategy that can be used to increase the community participation is to improve the process of extension.
\end{abstract}

Keywords: extension, community participation and national park.

\begin{abstract}
Abstrak
Penelitian ini bertujuan: (1) menjelaskan faktor-faktor yang berpengaruh pada partisipasi masyarakat dalam pengelolaan taman nasional Kepulauan Togean, (2) menganalisa peran penyuluhan dan hubungannya dengan partisipasi masyarakat, dan (3) Memformulasikan strategi penyuluhan dalam meningkatkan partisipasi masyarakat dalam pengelolaan Taman Nasional Kepulauan Togean (TNKT). Penelitian dilaksanakan di TNKT Sulawesi Tengah pada bulan Agustus sampai September 2008 dan Maret sampai April 2009. Terdapat lima variabel untuk mengukur partisipasi masyarakat dengan menggunakan analisa Structural Equation Model (SEM) dengan perangkat software LISEREL 8.30. Variabel tersebut adalah karakteristik internal, proses penyuluhan, faktor lingkungan, kapasitas dan partisipasi masyarakat. Hasil penelitian menunjukan bahwa proses penyuluhan berpengaruh nyata pada kapasitas masyarakat. Kapasitas masyarakat berpengaruh nyata terhadap partisipasi mereka dalam pengelolaan TNKT. Strategi yang dapat dilakukan untuk meningkatkan partisipasi adalah memperbaiki proses penyuluhan yang partisipatif yang memungkinkan masyarakat ikut serta dalam pengambilan keputusan mengenai pengelolaan TNKT..
\end{abstract}

Kata kunci: penyuluhan, partisipasi masyarakat dan taman nasional.

\section{Pendahuluan}

Pembangunan berkelanjutan (PB) (sustainable development), dan interdependensi ekonomi dan lingkungan (environment) merupakan konsep yang semakin penting di dunia sejak awal tahun 1970 an (Cole et al, 1973 dalam Sumardjo, 1999). Dalam laporan World Commission on Environment and Development tahun 1987, UN (PBB) berjudul Our Common Future, tercantum konsep pembangunan berkelanjutan tersebut. Bank Dunia pada tahun 1988 (Sumardjo, 1999), memasukkan proposisi bahwa pertumbuhan ekonomi (economic growth), pengentasan kemiskinan (the alleviation of poverty) dan manajemen lingkungan hidup (environmental management) harus mendapat perhatian secara konsisten dan terus menerus. Meskipun telah lama digagas, pencapaian tujuannya masih cukup rumit.

Konsep pembangunan berkelanjutan menjadi semakin penting mengingat perilaku masyarakat dalam mengembangkan usahanya berhubungan dengan pengelolaan sumberdaya alam, umumnya tidak sekedar tidak mampu meningkatkan pendapatannya tapi juga sekaligus merusak lingkungan hidup tempat sumber usaha. Amanah (2006:52) menguraikan dua masalah utama perilaku masyarakat dalam pemanfaatan SDA pesisir, yaitu: (1) usaha yang umumnya bersifat subsisten, keterbatasan modal, bergantung pada satu sektor usaha dan 
rendahnya kemauan dan kemampuan kegiatan pasca panen atau diversifikasi usaha, dan kesulitan pemasaran dan (2) perilaku dalam menangkap ikan yang merusak lingkungan dengan menggunakan kompresor dan zat kimia (potassium cyanide). Sinyalemen ini relatif serupa dengan apa yang terjadi di Kepulauan Togean yang menjadi lokasi penelitian ini.

Berbagai upaya untuk mewujudkan pembangunan berkelanjutan terutama dari segi ekologis di kepulauan Togean telah dilakukan, antara lain dengan penunjukan sebagai kawasan konservasi dalam bentuk Tanaman Nasional. Namun penunjukan ini masih menyisakan masalah yang pelik berkaitan dengan adaptasi dan transformasi perilaku serta respon terhadap konsep dan implentasi kawasan konservasi. Wilayah masyarakat yang sebelumnya terbuka (open acces) menjadi tertutup (close acces). Masyarakat yang sebelumnya bebas mengeksplotasi SDA manjadi terbatas dengan aturan main tertentu yang disyaratkan sebuah kawasan konservasi.

Kondisi ini mengisyaratkan tidak mudahnya mengajak masyarakat untuk ikut serta dalam suatu gagasan konservasi. Diperlukan faktor penunjang tertentu yang perlu dikaji dalam bentuk penelitian dan hasilnya diolah, disosialisasi dan diseminasi kepada masyarakat melalui penyuluhan. Oleh karena itu, penelitian ini mencoba menelaah faktor-faktor yang berpengaruh dalam meningkatkan partisipasi masyarakat dalam pengelolaan Taman Nasional Kepulauan Togean. Output penelitian ini adalah berupa rumusan strategi penyuluhan konservasi untuk mendorong partisipasi masyarakat dalam pengelolaan TNKT.

\section{Metoda Penelitian}

Metode yang digunakan dalam penelitian ini adalah metode survei dengan pendekatan analisis deskriptif dan paradigma kuantitatif sesuai pendapat Miller, Black dan Champion (Sumardjo, 1999). Penelitian dilakukan di Kepulauan Togean Kabupaten Tojo Una-Una Sulawesi Tengah, pada bulan Agustus-September .2008 .
Populasi penelitian adalah masyarakat Togean yang direpresentasikan oleh tiga desa yang dipilih secara sengaja "purposive sampling” yaitu; Lembanato Kecamatan Togean, Kabalutan Kecamatan Walea kepulauan dan Tanjung Pude Kecamatan Una-una. Sampel diambil secara acak berstrata (stratified ramdom sampling) (Singarimbun dan Efendi, 1989;162) dan disesuaikan dengan prosedur ukuran sampel dalam pengujian Struktural Equation Modeling (SEM) (Solimun, 2002). Berdasarkan rumus slovin diperoleh sebanyak 166 sampel. Terdapat juga 40 sampel informan dari tokoh masyarakat, pemerintah daerah dan NGO, sehingga seluruhnya berjumlah 206 sampel.

Seluruh data ditabulasi berdasarkan kategorinya, kemudian dianalisis sesuai kebutuhan penelitian. Untuk mengetahui hubungan dan pengaruh antar peubah serta model empirisnya digunakan analisis SEM dengan program LISREL. Pengujian model dilakukan dengan menggunakan beberapa ukuran kesesuaian, Goodness-of-Fit-Test (GFT). Menurut Joreskog \& Sorbon (Kusnendi, 2008:15), syarat sesuai (fit) suatu model struktural bila memenuhi tiga jenis GFT, yaitu: 1) $p$-value $\geq 0,05,2$ ) Root Means Square Error of Approximation (RMSEA) $\leq 0,08$, dan 3) Comparative Fit Indeks $(\mathrm{CFI}) \geq 0,90$.

\section{Hasil dan Pembahasan}

\section{Tingkat Penilaian Responden Berdasarkan Variabel Penelitian}

Tingkat penilain responden adalah tanggapan yang diberikan responden terhadap pertanyaan yang diajukan berdasarkan indikator dari varibel penelitian. Berikut ini diuraikan tingkat penilaian responsen terhadap variabel Karakteristik Individu, Proses Penyuluhan, Faktor Eksternal, Kapasitas Masyarakat dan Partisipasi Masyarakat.

\section{Karakteristik Internal}

Karakteristik internal yang diteliti meliputi beberapa komponen namun dua komponen yang merefleksikan variabel atau memiliki kecocokan model yang kuat yaitu; motivasi dan status sosial. Berdasarkan analisis model 
Tabel 1. Rataan Skor Karakteristik Individu (X1) di Kepulauan Togean

\begin{tabular}{ccccc}
\hline Peubah & $\begin{array}{c}\text { Tanjung Pude } \\
(\mathrm{n}=53\end{array}$ & $\begin{array}{c}\text { Lemba Nato } \\
(\mathrm{n}=55)\end{array}$ & $\begin{array}{c}\text { Kabalutan } \\
(\mathrm{n}=58)\end{array}$ & $\begin{array}{c}\text { Total Desa } \\
(166)\end{array}$ \\
\hline $\begin{array}{c}\text { X1 } \\
\text { Karakteristik Individu } \\
\text { X1.4 }\end{array}$ & 57 & 67 & 69 & 65 \\
$\begin{array}{c}\text { Motivasi } \\
\text { X1.7 }\end{array}$ & 64 & 80 & 76 & 73 \\
Status Sosial & 49 & 60 & 63 & 56 \\
\hline $\begin{array}{l}\text { Keterangan : Kategori penilaian: } 0-\leq 20=\text { sangat rendah; } 21-\leq 40=\text { rendah; } 41-\leq 60=\text { sedang; } 61-\leq 80= \\
\text { tinggi; } 81-\leq 100=\text { sangat tinggi. }\end{array}$
\end{tabular}

pengukuran tersebut, komponen motivasi dan status sosial memiliki keeratan atau validitas, reliabilitas dan kecocokan model yang kuat dalam membentuk faktor internal individu masyarakat di kepulauan Togean. Untuk melihat penilaian atas motivasi dan status sosial tersebut disajikan pada Tabel 1.

Tabel 1 menunjukan bahwa komponen motivasi umumnya berada pada kategori tinggi sedangkan komponen status sosial umumnya memiliki kategori sedang dan karakteristik internal yang dibentuk oleh kedua komponen tersebut berada pada kategori tinggi. Motivasi yang diukur dari sejumlah indikator manifest menunjukan bahwa masyarakat memiliki hasrat yang tinggi untuk terlibat dalam pengelolaan TNKT adalah guna mendapatkan manfaat yang besar baik untuk kepentingan usaha, permodalan, hasil yang meningkat, hubungan sosial dan penyelamatan lingkungan.

Kalau saat ini sering terjadi penyimpangan perilaku dalam pemanfaatan SDA disebabkan karena desakan dari dalam dan tekanan dari luar. Desakan dari dalam adalah kebutuhan keluarga dan dari luar karena masuknya pihak luar yang bersaing baik secara ilegal seperti mengambil hasil laut dengan menggunakan bahan berbahaya. Bahkan dalam beberapa kesempatan disinyalir terjadi kerja sama pihak luar membawa bahan berbahaya seperti bahan kimia dan bom untuk diserahkan kepada nelayan lokal

Untuk aspek status sosial mendapat penilaian sedang, menggambarkan bahwa masyarakat Togean memiliki percaya diri yang cukup baik menyangkut pengetahuan, kebendaan maupun kedudukan yang memungkinkan mereka bisa ikut dalam pengelolaan TNKT. Hal tersebut dibuktikan baik melalui berbagai pengetahuan dan praktek hubungan mereka dengan alam untuk memenuhi kebutuhan nafkah, maupun melalui kemudahan mereka dalam mengadopsi inovasi berkaitan dengan usaha ekonomi. Sebagai contoh, usaha budidaya rumput laut, teripang, berbagai jenis ikan dan mutiara adalah bidang yang pernah mereka geluti, namun tidak berjalan dengan baik, disebabkan beberapa faktor seperti; manajemen usaha dan keadaan eksternal seperti modal dan pemasaran serta aspek teknis seperti hama penyakit yang selalu menjadi kendala.

\section{Proses Penyuluhan}

Proses penyuluhan yang diteliti meliputi empat komponen yaitu; media, metoda, interaksi dan kemampuan penyuluh. Berdasarkan analisis model pengukuran, keempat komponen tersebut memiliki keeratan atau validitas, reabilitas dan kecocokan model yang kuat dalam membentuk faktor proses penyuluhan di TNKT. Hasil penilaian atas komponen tersebut disajikan pada Tabel 2.

Tabel 2 menunjukan bahwa komponen media penyuluhan, metoda dan kemampuan penyuluh berada pada kategori tinggi sedangkan komponen frekwensi penyuluhan memiliki kategori sedang dan proses penyuluhan yang dibentuk oleh keempat komponen tersebut berada pada kategori tinggi. Penilaian tinggi terhadap media dan metoda penyuluhan serta kemampuan penyuluh tersebut mengindikasikan bahwa masyarakat merasa puas dengan teknik penyuluhan yang dilakukan selama ini dan kapasitas penyuluh yang terlibat. Namun dari segi frekwensi penyuluhan, masyarakat memberi penilaian sedang, berarti intensitas penyuluhan masih perlu ditingkatkan. 
Tabel 2. Rataan Skor Proses Penyuluhan (X2) di Kepulauan Togean

\begin{tabular}{ccccc}
\hline Peubah & $\begin{array}{c}\text { Tanjung Pude } \\
(\mathrm{n}=53)\end{array}$ & $\begin{array}{c}\text { Lemba Nato } \\
(\mathrm{n}=55)\end{array}$ & $\begin{array}{c}\text { Kabalutan } \\
(\mathrm{n}=58)\end{array}$ & $\begin{array}{c}\text { Total Desa } \\
(166)\end{array}$ \\
\hline $\begin{array}{c}\text { X2 } \\
\text { Proses Penyuluhan } \\
\text { X2.2. }\end{array}$ & 59 & 61 & 69 & 63 \\
$\begin{array}{c}\text { Metode Penyuluhan } \\
\text { X2.3. } \\
\text { Media Penyuluhan } \\
\quad \text { X2.4 }\end{array}$ & 67 & 74 & 72 & 71 \\
$\begin{array}{c}\text { Interaksi Penyuluh } \\
\text { X2.5 }\end{array}$ & 63 & 52 & 72 & 62 \\
Kemampuan Penyuluh & 46 & 51 & 62 & 54 \\
\hline $\begin{array}{l}\text { Keterangan : Kategori penilaian: } 0-\leq 20=\text { sangat rendah; } 21-\leq 40=\text { rendah; } 41-\leq 60=\text { sedang; } 61-\leq 80=\text { tinggi; } \\
81-\leq 100=\text { sangat tinggi. }\end{array}$ & &
\end{tabular}

Bersadarkan hasil wawancara mendalam, diketahui bahwa penyuluhan yang dilakukan selama ini tertuju kepada tiga hal yaitu; usaha pertanian dan perikanan, konservasi dan lingkungan hidup serta manfaat TNKT. Namun, dari ketiga materi tersebut, keberadaan taman nasional tergolong materi atau isu yang yang relatif baru, dengan tingkat kesimpangsiuran yang sangat tinggi. Hal ini tidak diimbangi dengan intensitas penyuluhan yang tinggi pula sehingga masyarakat terombang ambing oleh ketidakjelasan status taman nasional dan manfaat yang diperoleh.

\section{Faktor Lingkungan}

Faktor lingkungan yang diteliti meliputi dua komponen yaitu; pemimpin informal dan kerjasama. Kedua komponen tersebut diperoleh melalui analisis model pengukuran untuk mengkonfirmasi lima komponen yang ditetapkan sebelumnya. Berdasarkan analisis model pengukuran tersebut, komponen pemimpin informal dan kerjasama memiliki keeratan atau validitas, reabilitas dan kecocokan model yang kuat dalam membentuk faktor lingkungan. Hasil penilaian atas kedua komponen tersebut disajikan pada Tabel 3.

Tabel 3 menunjukan bahwa komponen pimpinan informal dan kerja sama berada pada kategori tinggi dan faktor lingkungan yang dibentuk oleh kedua komponen tersebut juga berada pada kategori tinggi. Penilaian tinggi terhadap pimpinan informal dan kerja sama mengindikasikan bahwa masyarakat memberikan apresiasi yang tinggi terhadap peran pimpinan informal, saling percaya antar sesama dalam bentuk kerjasama baik untuk kepentingan sosial maupun ekonomi.

Berdasarkan hasil penelusuran informasi melalui FGD dan "Search conference" berkaitan dengan kepemimpinan dan kerjasama, terungkap bahwa asimilasi dan akulturasi budaya di antara penduduk mengakui institusi dan kelembagaan yang berlaku secara formal seperti pemerintahan dan pada beberapa etnis juga berlaku institusi dan kelembagaan informal yang dipimpin oleh pemimpin informal yang secara struktural tradisional tetap diakui,

Tabel 3. Rataan Skor Faktor Lingkungan (X3) di Kepulauan Togean

\begin{tabular}{ccccc}
\hline Peubah & $\begin{array}{c}\text { Tanjung Pude } \\
(\mathrm{n}=53)\end{array}$ & $\begin{array}{c}\text { Lemba Nato } \\
(\mathrm{n}=55)\end{array}$ & $\begin{array}{c}\text { Kabalutan } \\
(\mathrm{n}=58)\end{array}$ & $\begin{array}{c}\text { Total Desa } \\
(166)\end{array}$ \\
\hline $\begin{array}{c}\text { X3 } \\
\text { Faktor Lingkungan }\end{array}$ & 64 & 63 & 72 & 68 \\
$\begin{array}{c}\text { X3.2 } \\
\text { Kerjasama } \\
\text { X3.4 }\end{array}$ & 67 & 80 & 72 & 71 \\
Pimpinan Informal & 63 & 62 & 71 & 67 \\
\hline
\end{tabular}

Keterangan : Kategori penilaian: $0-\leq 20=$ sangat rendah; $21-\leq 40=$ rendah; $41-\leq 60=$ sedang $61-\leq 80=$ tinggi; $81-\leq 100=$ sangat tinggi. 
Tabel 4. Rataan Skor Kapasitas Masyarakat (Y1) di Kepulauan Togean

\begin{tabular}{|c|c|c|c|c|}
\hline Peubah & $\begin{array}{c}\text { Tanjung Pude } \\
(\mathrm{n}=53\end{array}$ & $\begin{array}{c}\text { Lemba Nato } \\
(n=55)\end{array}$ & $\begin{array}{c}\text { Kabalutan } \\
(\mathrm{n}=58)\end{array}$ & $\begin{array}{c}\text { Total Desa } \\
(166)\end{array}$ \\
\hline $\mathrm{Y} 1$ & & & & \\
\hline $\begin{array}{c}\text { Kapasitas Masyarakat } \\
\text { Y1.3 }\end{array}$ & 67 & 73 & 84 & 75 \\
\hline $\begin{array}{c}\text { Sikap Mental } \\
\text { Y1.4 }\end{array}$ & 55 & 75 & 88 & 78 \\
\hline Kesetaraan & 65 & 71 & 81 & 73 \\
\hline
\end{tabular}

yakni dewan adat yang berperan pemeliharaan etika kehidupan

Suku Bobongko mengenal struktur kepemimpinan yang terdiri dari tau $d a^{\prime} a$ (Pemimpin yang mempunyai garis keturunan raja), tolomato (kepala pemerintahan), talenga ulea (pembantu kepala pemerintahan) dan panabela (kepala kampung) serta lapisan. Masyarakat biasa (grass root). Beberapa pemimpin informal tersebut, dalam kehidupan sehari-hari sangat dibutuhkan misalnya dalam menentukan saat tanam dan panen serta waktu turun ke laut.

Selain dewan adat, pada beberapa etnis juga dikenal adanya sifat gotong-royong dalam kehidupan sehari-hari, misalnya masyarakat Bajo dikenal istilah bapongka, yaitu suatu kegiatan melaut secara berkelompok. Kegiatan bapongka dilakukan untuk mengumpulkan hasil laut seperti; teripang dan jenis ikan bergerombol (schooling fish) sejenis lolosi atau ekor kuning (Caesio sp) selama beberapa hari secara bersama sama.

\section{Kapasitas Masyarakat}

Faktor kapasitas masyarakat yang diteliti meliputi dua komponen yaitu sikap mental dan kesetaraan. Kedua komponen tersebut diperoleh melalui analisis model pengukuran untuk mengkonfirmasi empat komponen yang ditetapkan sebelumnya. Berdasarkan analisis tersebut, komponen sikap mental dan kesetaraan memiliki keeratan atau validitas, reliabilitas dan kecocokan model dalam membentuk faktor kapasitas masyarakat di TNKT. Hasil penilaian atas kedua komponen disajikan pada Tabel 4.

Tabel 4 menunjukan bahwa komponen Mentalitas dan Kesetaraan berada pada kate- gori tinggi dan faktor Kapasitas yang dibentuk oleh kedua komponen tersebut juga berada pada kategori tinggi. Penilaian tinggi terhadap sikap mental dan kesetaraan mengindikasikan bahwa masyarakat Togean, disamping memiliki adat istiadat yang masih dijalankan, juga memiliki sikap terbuka terhadap masuknya inovasi untuk kemajuan. Komponen kesetaraan yang diukur melalui pengetahuan, kemampuan dan percaya diri menunjukan bahwa masyarakat memiliki kapasitas yang memadai untuk menerima gagasan konservasi atau usaha ekonomi berkelanjutan.

Berdasarkan hasil wawancara mendalam serta penelusuran informasi melalui FGD dan SC menunjukan bahwa masyarakat memiliki kapasitas atau kemampuan tertentu yang sangat menakjubkan dalam mengelola ekosistem. Pada masyarakat Bajo misalnya, mereka memiliki kemampuan mengumpulkan hasil laut yang ditunjang pemahaman kondisi dan jenis karang yang diperoleh secara turun temurun. Mereka memiliki pembagian terhadap tipe terumbu karang yaitu sappa, lana, dan timpusu. Sedangkan dalam hal tehnik tangkap untuk memanfaatkan sumber daya laut, sebagaimana juga dijelaskan oleh Hutabarat (2001), masyarakat Bajo memiliki berbagai teknik tangkap, diantaranya missi (memancing), ngarua (memukat), mana (memanah dengan menggunakan alat tradisional), dan nyuluh/balobe atau yang biasa dikenal dengan ngobor (dengan menggunakan petromaks). 
Beberapa suku di Togean dalam memanfaatkan sumber daya alam terestrial (hutan) juga memiliki sistem pemanenan yang diperoleh secara turun-temurun. Mereka menerapkan beberapa aturan serta praktek pengelolaan sumberdaya alam yang ramah lingkungan dan berdampak positif terhadap kelestarian alam. Ini merupakan bentuk budaya lokal hasil dari proses adaptasi dan interaksi antara masyarakat Togean dan alamnya selama bertahun-tahun. Misalnya Orang Bobongko masih menerapkan hukum bayan dan aturan adat gogam pagaluman dalam pemanfaatan hutan sagu di Lembanato.

Dengan bergesernya kebutuhan ekonomi dan adanya desakan untuk melakukan pemungutan hasil laut dengan cara cepat, murah, mudah dan hasil besar, maka budaya ini mulai ditinggalkan. Sebagian nelayan menggunakan bahan peledak/bom, racun dan cara-cara tidak ramah lingkungan dalam menangkap ikan dan hasil laut lainnya. Hal yang sama juga terjadi di daerah pedalaman untuk praktek pertanian dan perkebunan.

\section{Partisipasi Masyarakat}

Partisipasi masyarakat dalam pengelolaan taman nasional yang diteliti meliputi beberapa komponen, namun hanya tiga komponen yaitu; tanggung jawab, manfaat dan relasi yang memiliki kecocokan model. Ketiga komponen tersebut diperoleh melalui analisis model pengukuran untuk mengkonfirmasi lima komponen yang ditetapkan sebelumnya. Berdasarkan analisis tersebut, komponen tanggung jawab, manfaat dan relasi memiliki keeratan atau validitas, reabilitas dan kecocokan model yang kuat dalam membentuk faktor Partisipasi masyarakat dalam pengelolaan TNKT. Hasil penilaian atas ketiga komponen tersebut disajikan pada Tabel 5.

Tabel 5 menunjukan bahwa komponen tanggung jawab, manfaat dan relasi berada pada kategori rendah dan Faktor Partisipasi Masyarakat yang dibentuk oleh kedua komponen tersebut juga berada pada kategori rendah. Penilaian rendah terhadap semua komponen ini mengindikasikan bahwa masyarakat tidak merasa puas dengan gagasan tentang adanya taman nasional kepulauan Togean. Mereka merasa tidak bertanggung jawab atau lebih tepatnya, tidak diberi tanggung jawab untuk ikut mengelola TNKT tersebut. Dari segi kegunaannya, masyarakat menganggap bahwa taman nasional tidak memiliki manfaat bagi kehidupan mereka. Selain itu mereka juga merasakan bahwa hubungan antar stakeholders taman nasional terutama dengan pihak pemerintah berkaitan dengan keberadaan taman nasional ini amatlah rendah.

Kenyataan ini menunjukan bahwa masyarakat Togean tidak teryakini akan manfaat dari keberadaan taman nasional sehingga tidak muncul rasa memiliki (sense of belonging) dan juga tidak hadir rasa tanggung jawab (sense of responsibility). Hal ini ditunjang oleh kurang gencarnya frekwensi penyuluhan yang dilakukan berbarengan dengan simpang siurnya informasi dan issu tentang keberadaan taman nasional. Pada saat bersamaan, masyarakat dikuatirkan dengan dampak kehadiran taman nasional berdasarkan referensi praktek sebelumnya di tempat lain. Selain itu, terdapat beberapa kenyataan hubungan buruk masyarakat

Tabel 5. Rataan Skor Partisipasi Masyarakat (Y2) di Kepulauan Togean

\begin{tabular}{ccccc}
\hline Peubah & $\begin{array}{c}\text { Tanjung Pude } \\
(\mathrm{n}=53\end{array}$ & $\begin{array}{c}\text { Lemba Nato } \\
(\mathrm{n}=55)\end{array}$ & $\begin{array}{c}\text { Kabalutan } \\
(\mathrm{n}=58)\end{array}$ & $\begin{array}{c}\text { Total Desa } \\
(166)\end{array}$ \\
\hline $\begin{array}{c}\text { Y2 } \\
\text { Partisipasi Masyarakat }\end{array}$ & 23 & 27 & 36 & 29 \\
$\begin{array}{c}\text { Y2.2 } \\
\text { Tanggung Jawab } \\
\text { Y2.3 } \\
\begin{array}{c}\text { Manfaat } \\
\text { Y2.4 }\end{array}\end{array}$ & 24 & 29 & 35 & 27 \\
Relasi & 26 & 31 & 38 & 32 \\
\hline
\end{tabular}

Keterangan : Kategori penilaian: $0-\leq 20=$ sangat rendah; $21-\leq 40=$ rendah; $41-\leq 60=$ sedang; $61-\leq 80=$ tinggi; $81-\leq 100=$ sangat tinggi . 
Tabel 6. Koefesien dan t-hitung penguruh karakteristik internal, proses penyuluhan dan faktor lingkungan pada kapasitas diri masyarakat.

\begin{tabular}{|l|c|l|c|c|c|c|}
\hline \multicolumn{2}{|c|}{ Hubungan antar Peubah/Sub Peubah } & $\begin{array}{c}\text { Pengaruh } \\
\text { langsung }\end{array}$ & $\begin{array}{c}\text { Pengaruh tdk } \\
\text { langsung }\end{array}$ & $t$-hitung & R2 \\
\cline { 1 - 6 } Karakteristik internal & $\longrightarrow$ & $\begin{array}{l}\text { Kapasitas } \\
\text { masyarakat }\end{array}$ & 0,12 & - & 0,98 & \\
\cline { 1 - 5 } Proses penyuluhan & $\longrightarrow$ & $\begin{array}{l}\text { Kapasitas } \\
\text { masyarakat }\end{array}$ & 0,60 & - & 3,87 & \multirow{2}{*}{0,33} \\
\cline { 1 - 5 } Faktor lingkungan & $\longrightarrow$ & $\begin{array}{l}\text { Kapasitas } \\
\text { masyarakat }\end{array}$ & $-0,23$ & - & 2,10 & \\
\hline
\end{tabular}

Keterangan : $t 0,05$ tabel $=1,96$

dengan aparatur setempat yang terkesan (berlebihan) dalam menangani pelanggaran pemanfaatan hasil alam laut maupun darat. Hubungan buruk ini oleh masyarakat dianggap sebagai akibat dari adanya TNKT.

\section{Faktor-faktor yang berpengaruh terhadap kapasitas masyarakat dan partisipasi mereka dalam pengelolaan TNKT}

Proses penyuluhan berpengaruh positif terhadap peningkatan kapasitas masyarakat dalam pengelolaan TNKT (Tabel 6). Penelitian terdahulu (Sumardjo, 1999 dan Subagyo, 2008) mengungkapkan bahwa syarat untuk menerapkan model peningkatan kapasitas melalui penyuluhan adalah ketersediaan penyuluhan baik kuantitas maupun kualitas serta dukungan organisasi penyuluhan. Dijelaskan lebih lanjut bahwa penyuluh profesional merupakan prasyarat terselenggaranya suatu penyuluhan yang dapat meningkatkan kapasitas petani. Oleh karena itu, peningkatan kapasitas masyarakat harus dimulai dari upaya untuk meningkatkan kapasitas penyuluh.

Meningkatnya faktor lingkungan berpengaruh pada menurunnya kapasitas masyarakat dalam pengelolaan TNKT (Tabel 6). Secara kontekstual dapat dijelaskan bahwa isu dan informasi yang simpang siur tentang keberadaan taman nasional menimbulkan suasana yang tidak kondusif dalam hubungan antar aktor. Kondisi ini menimbulkan suasana pro dan kontra yang mengarah kepada konflik horisontal maupun vertikal. Akibatnya, segala yang berkaitan dengan taman nasional selalu ditanggapi negatif. Suasana konflik ini berkontribusi pada delegitimasi peran aktor.
Hingga rangkaian penelitian ini berakhir, keadaan cenderung tidak pasti akibat konflik kepentingan (ketidaktahuan atau ketidakjelasan wewenang serta lemahnya koordinasi) berbagai aktor TNKT. Masalah ini menjadi makin rumit karena konflik tidak hanya melanda masyarakat dengan pemerintah, tapi juga antar pemerintah lokal dan pemerintah pusat baik soal kejelasan status maupun kekisruhan Tata Ruang Nasional terkait dengan TNKT.

Meningkatnya karakteristik individu berpengaruh pada menurunnya partisipasi masyarakat dalam pengelolaan TNKT (Tabel 7). Kenyataan ini secara emperik disebabkan masyarakat menyangsikan manfaat kehadiran taman nasional di wilayah mereka. Berdasarkan teori partisipasi, masyarakat akan tergerak mau terlibat bila mereka meyakini manfaatnya (Eberley, 2007). Gambaran buruk praktek taman nasional di berbagai daerah menimbulkan sikap penolakan masyarakat terhadap eksistensi TNKT. Masyarakat mengangap bahwa kehadiran taman nasional akan membatasi ruang gerak mereka untuk mencari nafkah, padahal motivasi mereka yang tinggi untuk berpartisipasi di TNKT justru untuk mengakses lahan usaha dengan mudah.

Kapasitas Masyarakat berpengaruh nyata terhadap partisispasi mereka dalam pengelolaan TNKT (Tabel 7). Pengaruh ini sangat berarti karena kapasitas masyarakat dianggap salah satu faktor yang menentukan bagi masyarakat untuk berpartisipasi. Menurut Slamet (2003) dan Wilson and Koester (2008), syarat terjadinya partisipasi adalah kemampuan, disamping kemauan dan kesempatan. Ramirez (Suporaharjo, 2005), mengemukakan bahwa masyarakat secara umum adalah stakeholder 
Tabel 7. Koefesien dan t-hitung penguruh karakteristik internal, proses penyuluhan, faktor lingkungan dan kapasitas terhadap partisipasi.

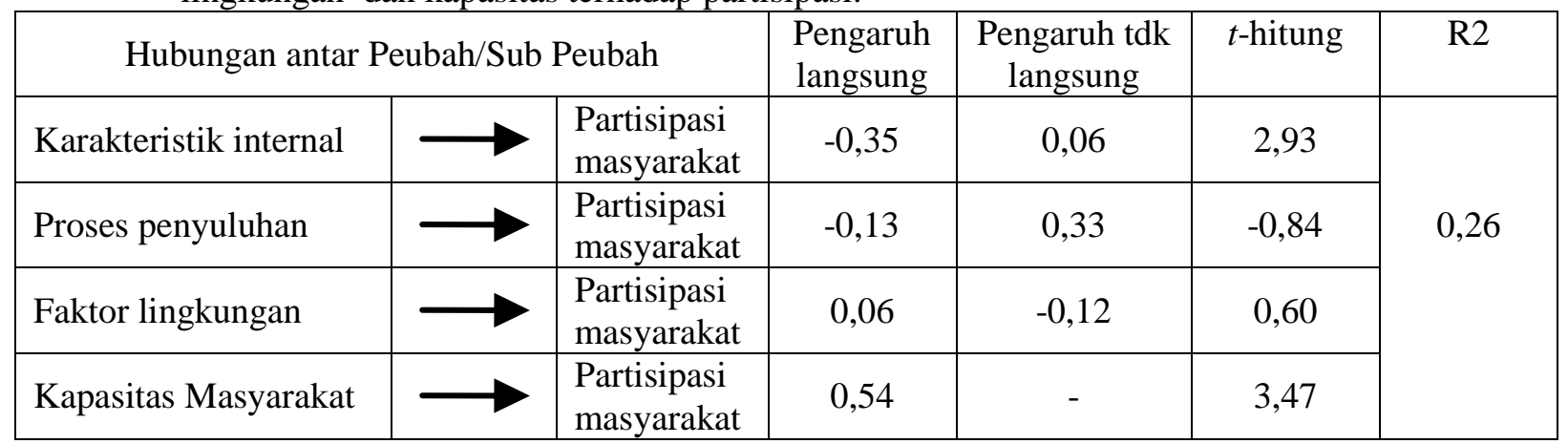

Keterangan : $t 0,05$ tabel $=1,96$

terhadap objek yang melekat, tapi stakeholder masih dapat diidentifikasi sebagai aktor sosial, yaitu mereka yang mempunyai kapasitas untuk berpartisispasi terutama dalam proses pengambilan keputusan. Namun, kapasitas yang meningkat saja tidak otomatis menyebabkan meningkat partisipasi karena ada faktor penentu lain yaitu peluang atau kesempatan.

\section{Hubungan antar faktor yang berpengaruh terhadap kapasitas dan partisipasi masyarakat}

Terdapat hubungan yang erat antara karakteristik individu, proses penyuluhan dan faktor lingkungan. Hubungan karakteristik individu dan proses penyuluhan maupun proses penyuluhan dan faktor lingkungan bersifat positif (Tabel 8). Keeratan hubungan ini sekaligus mengisyaratkan peran sentral proses penyuluhan dalam meningkatkan partisipasi baik melalui internal individu, faktor lingkungan maupun kapasitas masyarakat.

Bila intervensi dalama bentuk penyuluhan yang partisipatif (konvergen) dan holistik berkaitan dengan eksistensi TNKT akan berkontribusi positif bagi pemahaman, motivasi, kemampuan dan peluang masyarakat untuk berpartisipasi. Penyuluhan yang benar akan merubah anggapan masyarakat yang keliru tentang taman nasional. Selain itu akan meningkatkan kemampuan masyarakat dalam mengelola TNKT dan SDA secara berkelanjutan. Penyuluhan ini selanjutnya akan membangkitkan rasa mememiliki dan tanggung jawab mayasarakat terhadap keberlanjutan kawasan tempat mereka bermukim.

\section{Strategi Penyuluhan Konservasi untuk Pengembangan Partisipasi Masyarakat dalam Pengelolaan TNKT}

Sintesis dari hasil penelitian ini diperoleh Strategi Pengembangan Partisipasi masyarakat dalam pengelolaan TNKT melalui proses penyuluhan dengan tahap-tahap sebagai berikut :

Tahap pertama, adalah analisis dan identifikasi kebutuhan secara partisipatif:

Pada tahap ini, penyuluh dan masyarakat harus dapat mengidentifikasi dan menentukan kebutuhan yang dirasakan (felt

Tabel 8. Arah, koefisien dan t-hitung dari hubungan peubah karakteristik internal, proses penyuluhan dan faktor lingkungan.

\begin{tabular}{|l|c|l|c|c|}
\hline \multicolumn{3}{|c|}{ Hubungan antar Peubah } & $\begin{array}{c}\text { Arah/koefisien } \\
\text { Hubungan }\end{array}$ & $t$-hitung \\
\hline Karakteristik Individu & $\longrightarrow$ & Proses penyuluhan & 0,50 & 6,43 \\
\hline Proses penyuluhan & $\longrightarrow$ & Faktor lingkungan & 0,56 & 9,80 \\
\hline Faktor lingkungan & $\longrightarrow$ & $\begin{array}{l}\text { Karakteristik } \\
\text { individu }\end{array}$ & 0,28 & 3,26 \\
\hline
\end{tabular}

Keterangan : $t$, 0,05 tabel $=1,96$ 
need) dan kebutuhan sesungguhnya (real need) berkaitan dengan kehadiran TNKT.

Berdasarkan hasil penelitian teridentifikasi bahwa kebutuhan masyarakat yang dimanifestasikan dalam sub peubah motivasi mendapat skor tinggi pada beberapa indikator seperti kebutuhan akan akses permodalan, ruang atau lokasi usaha dengan hasil yang memadai (akses ruang dan SDA) serta keinginan untuk menjaga kelestarian alam dan menjalin hubungan sosial dengan sesama (jaminan keberlanjutan).

Tahap kedua, adalah proses penyuluhan yang dapat meningkatkan kapasitas dan partisipasi:

Prasyarat untuk menerapkan model dan strategi peningkatan kapasitas melalui proses penyuluhan adalah ketersediaan penyuluh baik kualitas mapun intensitasnya serta dukungan kebijakan yang memadai. Penyuluh yang berkualitas juga seperti diungkap Asngari (2003), harus memahami falsafah penyuluhan dan mempraktekannya.

Berdasarkan temuan penelitian ini, semua upaya ini baru akan efektif bila diimbangi dengan pemberian kesempatan (oportunity), kepercayaan (trust) dan penghargaan atau pengakuan akan hak masyarakat lokal (recognition) dan pelibatan dalam proses pengambilan keputusan. Dengan kata lain strategi pendekatan harus bersifat komprehensif berupa penyuluhan (pemberdayaan) partisipatif dalam bentuk pendampingan terpadu. Penyuluhan partisipatif memungkinkan tergalinya kebutuhan real masyarakat dan pendampingan terpadu akan menjadi jembatan bagi terpecahkannya masalah secara holistik atas dukungan semua aktor terkait.

Tahap Ketiga: adalah keluaran (output) yaitu terjadi peningkatan motivasi dan kapasitas masyarakat sebagai hasil proses penyuluhan yang benar:

Ukuran keberhasilan penyelenggaraan penyuluhan adalah perubahan perilaku masyarakat yang ditunjukan oleh kapasitas yang tinggi dalam hal keterbukaan menerima inovasi, pengetahuan dan kemampuan dalam usaha ekonomi yang ramah lingkungan serta tingkat kepedulian pada penyelamatan SDA.

Dibutuhkan transformasi perilaku dari kebiasaan memanfaatkan SDA secara bebas ke penggunaan terbatas dengan memperhitungkan daya dukung dan keberlanjutannya. Disadari bahwa akan terjadi dilema antara kepentingan jangka pendek dan jangka panjang. Ide moratorium misalnya, akan berhadapan dengan hilangnya peluang usaha harian (one day fishing) untuk nafkah atau ekonomi keluarga (job oportunity). Namun bila tidak dilakukan moratorium maka stok SDA makin menipis dan akan punah satu ketika sehingga masyarakat kehilangan kesempatan usaha secara parmanen. Hal yang lebih menyedihkan lagi adalah bila SDA tersebut tergolong "endemik" yang amat bernilai ekonomi, sosial maupun ekologi.

Tahap ke empat adalah manfaat (outcome), akibat meningkatnya kapasitas masyarakat yang diwujudkan dalam bentuk partisipasi dalam pengelolaan TNKT.

Terdapat tiga parsyarat bagi lahirnya partisispasi yaitu; kemauan, kemampuan dan kesempatan. Faktor kemauan berhubungan dengan motivasi dan motivasi yang amat kuat selalu berkaitan dengan manfaat yang diperoleh. Hanya masyarakat yang merasa memperoleh manfaat dari suatu anjuran, akan mau mengikuti anjuran tersebut.

Jika tidak ada cara memberi keuntungan bagi masyarakat lokal untuk upaya konservasi berarti tidak adil bila mengharapkan mereka mengorbankan kebutuhannya demi cita cita konservasi. Oleh karena itu, pendekatan partisipasi dalam bentuk penyuluhan dan pemberdayaan di bidang pembangunan dan konservasi harus diimbangi dengan upaya pembagian manfaat "sharing benefit" misalnya insentif ekonomi, jaminan akses SDA atau kompensasi terhadap peluang usaha yang hilang, terhalang atau tertangguhkan, karena wilayahnya dijadikan kawasan konservasi.

Agar partisipasi masyarakat dalam pengelolaan TNKT terarah dan bertanggung jawab maka perlu ada wadah (formal atau 
informal) untuk memfasilitasi proses partisipasi masyarakat dalam pengelolaan TNKT.

Tahap ke lima adalah dampak (impact) dari proses penyuluhan, peningkatan, motivasi, kapasitas dan partisipasi masyarakat dalam pengelolaan TNKT:

Hasil jangka panjang tersebut dicirikan oleh meningkatnya kesejahteraan masyarakat dan terjaganya lingkungan hidup secara lestari. Pada tahap ini telah muncul pemahaman dan kesadaran bersama akan pengelolaan sumber daya alam secara berkelanjutan.

Untuk menjamin proses ini berkesinambungan, dibutuhkan intervensi dukungan kebijakan karena motivasi dan kapasitas yang dibangun dari proses penyuluhan saja tidaklah menjadi jaminan bangkitnya partisipasi. Kebijakan tersebut berkaitan dengan kemauan politik dalam bentuk aturan hukum dan diimplementasikan dalam wujud program. Program ini hendaknya dapat menjamin keharmonisan antara pengembangan ekonomi, kelestarian lingkungan dan hak-hak masyarakat lokal.

\section{Kesimpulan}

Faktor-faktor yang dapat meningkatkan partisipasi masyarakat dalam pengelolaan TNKT adalah kapasitas diri masyarakat melalui peningkatan efektivitas proses penyuluhan. Proses penyuluhan menjadi kunci peningkatan partisipasi asalkan diikuti dengan kebijakan penerapan secara konsisten, konsep kolaborasi dalam pengelolaan TNKT. Strategi yang dapat digunakan adalah meningkatan proses penyuluhan yang partisipatif yang memungkinkan masyarakat ikut dalam proses pengambilan keputusan berkaitan dengan pengelolaan TNKT.

Perlu meningkatkan secara berkesinambungan proses penyuluhan baik menyangkut peningkatan produksi maupun konservasi melalui peningkatan kualitas penyuluh dan kuantitas penyuluhan.

Pemerintah perlu segera memberikan kejelasan status dan penerapan konsep kolaboratif dalam pengelolaan TNKT dengan pendekatan penyuluhan partisipatif. Partispasi masyarakat dalam hal konservasi mutlak didorong, selain sebagai bentuk pengakuan (recognition), juga karena hidup mereka amat tergantung pada SDA di sekitarnya. Untuk itu, perlu ada mekanisme yang menjamin akses mereka kepada sumberdaya atau kompensasi atas akses mereka yang terhambat.

\section{Daftar Pustaka}

[CII] Conservation International Indonesia. 2005. Konservasi Berbasis Masyarakat Melalui Daerah Perlindungan Laut Di Kepulauan Togean. Palu : CII Togean Program

Cohen, J. Uphoff N. 1980. Participation place in rural development : seeking clarity trough Specificity. J. World Development Vol 8.

[Dephut] Departemen Kehutanan. 1990. Undang-Undang No. 5 Tahun 1990 Tentang Konservasi Sumberdaya Alam Hayati dan Ekosistemnya. Jakarta Dephut. ,. 2004. Peraturan Menteri Kehutanan No. P.19/Menhut-II/2004 Tentang Kolaborasi Pengelolaan Kawasan Suaka Alam dan Kawasan Pelestarian Alam. Jakarta. : Dephut.

Eberley, W. 2007. Stakeholder participation in poverty reduction. [INEF Report 86]. Duisburg: Institute For Development and Peace.

Kusnendi. 2008. Model-Model Persamaan Struktural. Satu dan Multigroup Sampel dengan LISREL. Bandung: Alfabeta.

Sahidu, A. 1986. Partisipasi masyarakat tani pengguna lahan sawah dalam pembangunan pertanian di daerah Lombok, Nusa Tenggara Barat. [Disertasi]. Bogor: Program Pascasarjana. Institut Pertanian Bogor.

Singarimbun, M. Effendi S. 1995. Metode Penelitian Survei. Jakarta: LP3S.

Slamet, M. 2003. Meningkatkan Pertisipasi Masyarakat dalam Pembangunan Perdesaan. Di dalam: Yustina I, Sudrajad A, editor. Membentuk Pola Perilaku Manusia Pembangunan. Bogor: IPB Press. 
Solimun. 2002. Multivariate Analysis. Struktural Equation Modeling (SEM), Lisrel dan Amos. Malang Universitas Brawijaya.

Subagyo, H. 2008. Peranan kapasitas petani dalam mewujudkan keberhasilan usaha tani: kasus petani sayuran dan padi di kabupaten Malang dan Pasuruan Provinsi Jawa Timur. [Disertasi]. Bogor: Sekolah Pascasarjana IPB.
Sumardjo. 1999. Transformasi model penyuluhan pertanian menuju pengembangan kemandirian petani. kasus di Provinsi Jawa Barat. [Disertasi]. Bogor: Program Pascasarjana IPB.

Suporahardjo. 2005.Manajemen Kolaborasi. Memahami Pluralisme Membangun Konsensus. Bogor : Pustaka Latin.

Wilson E, Koester D. 2008. Community participation in international projects; an analitical perspective from Rusia Far East. J. Environment Development Sustain. Vol 10. 